\title{
GUEST PASSENGER DISCRIMINATION
}

\author{
DALE GIBSON*
}

\begin{abstract}
Gratuitous passengers must prove gross negligence to succeed against the driver in all provinces, except Quebec. The circumstances which gave rise to gratuitous passenger legislation are no longer applicable, says Professor Gibson, nor are the reasons valid for maintaining the guest passenger status. He concludes that the legislation has outlived its usefulness and should be repealed.
\end{abstract}

About one-third of those who are accidentally killed or injured by automobiles in Canada are guest passengers. ${ }^{1}$ An accident compensation system which ignored this huge category of victims would clearly be defective, yet that is exactly what Canadian law does." Section 211 of the Alberta Highway Traffic Act, ${ }^{3}$ which is typical of the provincial statutes, states that a driver who negligently kills or injures a guest passenger in his own automobile is not legally obliged to provide compensation unless he is guilty of "gross negligence or wilful and wanton misconduct," and because the "ordinary" types of negligence that cause most automobile accidents do not come within the meaning of that term, most guest passengers injured by their driver's negligence go uncompensated. And even when the victim can show that the driver was guilty of gross negligence or wilful and wanton misconduct, he is not entitled to compensation from the driver's insurance company unless the driver has a special type of insurance coverage, requiring an extra premium. ${ }^{4}$

Repeal of this legislation, while no substitute for the more radical reforms in automobile compensation that are so badly needed, ${ }^{5}$ would alleviate the harshest feature of existing traffic accident law, and could be accomplished without altering any basic legal notions. Indeed, abolition of this legislation would represent a return to basic common law principles.

The common law did not discriminate against guest passengers in this way. It is true that liability to guest passengers for injuries caused by the defective condition of the vehicle or premises was restricted, but there was no such limit to the driver's liability for careless driving. ${ }^{6}$ The Supreme Court of Canada settled the matter in 1926 by holding that negligent drivers are legally liable to their guest passengers, just as they are to pedestrians or other motorists whom they injure. ${ }^{7}$

\footnotetext{
- Associate Professor, University of Manitoba Faculty of Law. This article is based on a submission made to the Special Committee on Automobile Insurance of the Manitoba Legislature in November, 1967.

1 Dominion Bureau of Statistics, Motor Vehicle Traffic Accidents, October-December, $1966,4$.

2 The various provincial statutes involved are collected in (1960), 38 Can. B. Rev. 47.

3 See section 296 of the Alberta Insurance Act, R.S.A. 1955, c. 159.

5 See, for example, Keeton and $O^{\prime}$ Connell, Basic Protections for the Traffic Victim, 1965 Guest passenger discrimination must be ended regardless of what is done about non-fault automobile insurance. In fact, if an insurance scheme enabled some guest passengers to be compensated regardless of fault, a law that required the remainder passengers to be compensated regardless of fault, a law that required the remainder of them to prove gross negligence would be even more anomalous than at present. Even if a universal non-fault scheme were instituted, the guest
continue to apply to claims extending beyond the policy limits.

6 Failure to make this distinction led the All Canada Insurance Federation to the erroneous assertion, in its Brief to the Select Committee of the Manitoba Legislature on Automobile Insurance 11. that Canadian law prior to 1926 imposed liability to guest passengers only in cases of gross negligence. See Wright (1941), 19 Can. B. Rev. 465, $477 \mathrm{ff}$.

i Armand v. Carr, [1926] S.C.R. 575.
} 
After this decision, the automobile insurance industry campaigned to persuade legislatures in Canada and the United States to pass statutes making drivers immune from legal liability to their guest passengers. It was a very successful campaign. In 1927 legislation was passed in three states (Connecticut, Iowa and Oregon) ${ }^{\circ}$ and by 1939 similar laws were in force in 27 American states and in all Canadian provinces except Quebec. $^{9}$ The campaign apparently came to an end in 1939; no new guest passenger statutes have been passed since then. In some places the statute went so far as to deny the guest passenger's right to sue in any circumstances, however reckless his driver; but since the amendment of the Ontario act in 1966, all guest passenger legislation now restricts recovery to situations of gross negligence or wilful and wanton misconduct. ${ }^{10}$

The change was sometimes brought about in stages. In Alberta, for example, the Insurance Act was amended first, in 1933, to provide that no insurance company would be responsible for its drivers' liability to passengers unless the policy contained a special endorsement, for which an extra premium was charged." Then, in 1934, the driver's liability to guest passengers was limited to situations of gross negligence or wilful and wanton misconduct. ${ }^{12}$

That these changes were brought about virtually without the knowledge of the public can be seen by examining the newspapers of the time. In Manitoba, for example, where no record was kept of the legislative debates at the time, the entire newspaper coverage of the 1935 amendment in Winnipeg was three sentences in the Tribune, and two and one-half sentences in the Free Press, all buried in stories on other subjects. ${ }^{13}$ No newspaper reference to the 1932 change could be found.

What are the reasons advanced in support of this legislation? The following seem to be the main ones:

(a) Fairness to Driver-The reason which, on its face would probably appeal most strongly to the average legislator, has been expressed as follows by the Saskatchewan Court of Appeal: "This legislation was doubtless prompted by a general feeling that it was unjust that a passenger should be able to recover damages from a generously minded motorist who had given him a lift."14

This may be an accurate assessment of what was "just" when the legislation was passed in the late 1920's and early 1930's (even of that I am doubtful), but circumstances have changed so drastically since then that it is no longer appropriate.

At the time this legislation was passed, in the depth of the depression, private automobiles were in common use, but they had not yet become the "necessity" they are today. It could perhaps be fairly said then that a person who accepted a lift from another was truly "getting something for nothing." As one writer points out, hitch-hiking was, during the depression years, one of the principal means of transportation for vast

8 (1930), 18 Calif. L. R. 184.

9 Linden (1962), 40 Can. B. Rev. 284, 285, n. 9.

10 The Saskatchewan act now restricts liability to wilful and wanton misconduct: R.S.S. 1965, c. 377, s. $168(2)$.

11 S.A. 1933, c. 57, s. 4. See n. 4

12 S.A. 1934 , c. 62, s. 9. See n. 3.

13 Tribune, March 12, 1935; Free Press, April 1 and April 8, 1935

it Sortt v. Rush |1937| 4 D.L.R. 62, 66 (1) per Mackenzie. J. A. 
numbers of restless unemployed persons. ${ }^{1 ;}$ Nowadays, automobile transportation is a feature of almost everyone's life, and providing or accepting free rides is part of their daily routine. Most people accept free transportation as frequently as they provide it for others. No longer can it be said, therefore, that the average guest passenger is getting "something for nothing." Prevailing behavior patterns dictate that he should reciprocate when he is able to do so by offering rides to others.

An even more significant change has taken place in regard to liability insurance. Before the legislation was passed, any "unfairness" involved in allowing a guest passenger to sue his driver could only arise with respect to uninsured motorists. A judgment against an insured driver by a guest passenger would be paid by the driver's insurance company, the only adverse effect on the driver being an increase in his insurance premium-an insignificant detriment compared to the compensation benefits received by the injured passenger. And it could not be regarded as "unfair" to the insurance companies to require them to compensate guest passengers, since they simply took the cost of doing so into account in setting premium rates. Since that time, automobile liability insurance has come into such common use that almost all drivers are now insured. Therefore, any "unfairness" that might at one time have been involved in requiring an uninsured driver to compensate an injured guest passenger would almost never arise today if the guest passenger sections were repealed. It just is not realistic any more to speak of "fairness to the driver."

Probably the most important alteration in circumstances between the 1930's and the 1960's has been a profound change in our thinking about legal liability for negligent conduct generally.

Until the early 1930's it was thought unfair to make anyone liable for negligent conduct unless he either stood in a very close relationship to the injured party (e.g. a parent), or had received some kind of compensation for undertaking to be careful. The legal rules that reflected this thinking resulted in many innocent persons, injured by the negligence of others, being denied compensation. Gradually, a sense of the unfairness of this situation began to develop and culminated in a 1932 decision of the House of Lords which rejected the old rule and substituted a new broader basis for liability. ${ }^{16}$ This decision has been widely followed, with the result that today, generally speaking, a person who negligently injures another is legally liable to compensate him, even though he bears no special relationship to him and has received no compensation. For example, if a passerby sees an injured person lying in the street and undertakes to render first aid, he will be legally liable if he does so carelessly, in spite of the voluntary nature of the act.

This broadening of the basis of liability has not unduly prejudiced defendants because it has, as we have seen, been accompanied by a marked increase in the use of liability insurance to spread the risk.

It is true that a few exceptional types of situation still exist where the courts continue to apply the old rule, and base liability for negligence on the existence of a special relationship or compensation. However, these exceptions are speedily being reduced by judicial and legislative

18 Kushner, The Gratuitous or Guest Passenger (1958), 30 Man.B.N. 57, 58.

10 Donoghue v. Stevenson, [1932] A.C. 562. 
action. For example, until recently the courts refused to make a person legally liable for the economic consequences of his negligent statements (as opposed to acts) unless he owed the plaintiff a contractual duty of care. But a few years ago the House of Lords in England announced its intention to narrow this exception and to award liability in some circumstances for even gratuitously made misstatements. ${ }^{17}$ Canadian courts have already begun to apply this new rule. ${ }^{18}$

An exception which continues to exist, and which many feel is analogous to the guest passenger situation, relates to guests in another's home or other premises. Here the degree of liability of the occupier varies according to whether or not he has received a material benefit from the presence of the guest. There are some who feel that this justifies the guest passenger legislation. I disagree. In the first place it is much easier to establish that an occupier has a "material interest" in his guest's presence than it is to show that a driver has received "payment" from a guest passenger. Secondly, the standard of care which an occupier owes even to a gratuitous guest is higher than that owed by a driver to a gratuitous passenger; the occupier could be liable for conduct falling considerably short of gross negligence or wilful and wanton misconduct. Thirdly, and most important, the occupier's liability rule has itself been subjected to increasingly severe criticism in recent years. This dissatisfaction led in England to a 1957 statute abolishing the rule, and making occupiers liable for the negligence to every class of entrant except trespassers. ${ }^{10}$ Since then there has been increased pressure in most parts of the common law world for adoption of similar legislation. So even in this area the trend is to abolish exceptions to the general principle that everyone ought to be responsible to others injured as a result of his negligent conduct.

In summary, I feel that even if it was fair in the 1930's to restrict the liability of negligent drivers and their insurance companies to guest passengers, circumstances have changed so radically since then that this is no longer true. On the contrary, the present law is manifestly unfair to injured passengers.

(b) Fairness to Insurer-

It is possible that the subsection was passed to offset the damage done to insurance companies by earlier legislation that made the owner of a motor vehicle responsible for loss caused by it in addition to the driver, and shifted the onus of proof to the owner or driver in pedestrian cases. ${ }^{20}$

If this was one of the reasons for discriminating against guest passengers, it does not seem to me to be a justifiable one. The only justification for altering the general law is to further the public good, not to compensate special interests for collateral wrongs. The appropriate way to compensate insurance companies for imposing increased liability is by allowing them to charge higher premiums, and this has been done. What sense is there in imposing unusually high liability to one class of plaintiff (pedestrians) at the cost of unusually low liability to another class (passengers)?

(c) Prevention of Collusion-This is probably the most frequently ad-

17 Hedley Byrne \& Co. v. Heller [1963] 2 All E.R. 575.

18 In Dodds v. Millman (1964), 45 D.L.R. (2d) 472 the B.C. Supreme Court followed the Hedley Byrne dictum.

19 Occupiers Liability Act, 1957, 5 \& 6 Eliz. 2, c. 31.

20 Linden, op. cit. supra, n. 9, at 286. 
vanced reason. As a member of the Saskatchewan Court of Appeal put it, this legislation "protected the insurance companies against possible collusion between the passenger and the motorist when the latter happened to be insured."21

There can be no doubt that when a friend is injured while riding as a guest passenger in the driver's car, there may sometimes be a temptation for the driver to exaggerate his own carelessness, in order to ensure that the passenger will be able to recover from the insurance company. I deny, however, that the risk is as serious as it is made out to be, or that the prevailing guest passenger legislation is a very effective remedy.

First, let us consider the type of situation in which the temptation is likely to arise. We must exclude all those cases in which the driver actually was negligent (which, I think everyone familiar with automobile accidents would agree, would be the majority of cases), since it is not improper to admit negligence if the admission is true. Of the remaining cases, we must also exclude most of those in which another insured motorist is involved, since in those situations the much more natural instinct to lay the blame on the other driver would be as helpful to your injured passenger as admitting your own carelessness. It is, therefore, only in cases where there is no insured defendant, and the driver was not at all negligent, that the temptation of collusion will arise. Although I do not have any statistics on the subject, I suspect that this represents only a very small fraction of the total cases involving injuries to guest passengers.

Next, let us consider the likelihood that a driver who finds himself in this rare situation will yield to the temptation. To do so involves, first, the ability to overcome the normal human reluctance to admit that one in wrong. This reluctance is strong even when one really is wrong; it must be exceedingly difficult to overcome when one is actually in the right. Second, every driver who admits negligence knows that he is risking an increase in insurance premiums, and perhaps also a criminal prosecution and a mark against his driving record. And if the admission is a lie, he knows that he is also risking conviction for perjury and cancellation of his insurance if the truth is discovered. Finally, honesty must play some role. I acknowledge that honesty does not exert a powerful influence on the average man's attitude toward impersonal organizations like insurance companies, but I submit that it would lead some drivers to resist the temptation to lie, if only by providing them with a way of justifying to the passenger and themselves a decision based in reality on fear of the consequences.

Even if a substantial risk of collusion did exist in guest passenger cases, how effective a deterrent would be provided by prevailing guest passenger legislation? The legislation that used to exist in Ontario and a few other places was very effective-it prohibited recovery by a guest passenger under any circumstances, so it completely wiped out any occasion for collusion. But the present provincial legislation is not nearly so effective. The passenger may recover if he can prove that the driver was "grossly negligent." If a driver is determined to lie, there is nothing to stop him from admitting to acts that constitute "gross negligence." It

21 Maclsenzto, J. A., op. cit. oupra, n. 14, at 66. 
is true that he would have to have some knowledge of what the courts regard as "gross negligence," but this information is not difficult to obtain. It is also true that he would be taking a greater risk of criminal liability by admitting to a greater degree of carelessness, but if he is prepared to take the risk in the first place, he will probably not be deterred by a slight increase in the risk. The section which denies insurance company liability to any passengers is an effective deterrent, of course, but it does not operate where the company provides passenger coverage for an extra premium.

In summary, then, the guest passenger legislation acts as a deterrent to collusion only in cases where:

(a) the driver was not negligent, and

(b) there was no other insured defendent involved, and

(c) the driver is prepared to say that he was negligent, in spite of - the natural desire to appear in the right, - the urge for honesty, - the fear of criminal prosecution for negligent driving or perjury, increased premiums and cancelled insurance, and

(d) the driver is not prepared (or not aware of the need) to say that he was grossly negligent.

If it is not already obvious that this combination of circumstances would arise in only an insignificant percentage of guest passenger claims, that fact can be proved statistically. According to the All Canada Insurance Federation, in its brief to the Select Committee of the Manitoba Legislature, claims by guest passengers against their drivers accounted for about 30 per cent of the claims dollars paid before the legislation was changed. ${ }^{22}$ The Federation stated that "it was regarded as a notorious fact that this was primarily due to collusion between the driver and his passenger." However, if the spokesmen for the Federation had reminded themselves that about 30 per cent of all automobile injuries also involve guest passengers, ${ }^{23}$ they would have realized that their statistics prove exactly the opposite: that the risk of collusion has no significant effect on the volume of successful claims by guest passengers.

(d) Cost-I suspect that the real reason for passing guest passenger legislation in many provinces was a financial problem that faced automobile insurance companies during the 1930's. The ratio of losses paid to premiums earned was rising alarmingly during that period. Normally, such a situation would call for increased premiums, but this was not a realistic solution in the depth of the depression. Understandably, therefore, insurance companies sought ways of reducing the loss-premium ratio by diminishing the risk covered. In 1932, the year the amendment was passed in Manitoba (1933 in Alberta) removing insurance company liability for passengers except for an extra premium (and limiting the risk in other ways as well), the ratio in that province was 51.9 per cent. It fell to 41 per cent the next year. Unfortunately, it quickly rose again, reaching an alarming 57.5 per cent in 1935 , when the guest passenger section was passed by the Manitoba Legislature (1934 Alberta legislation). The next year it dropped to 54.3 per cent. ${ }^{24}$ Undoubtedly there were many factors at work to produce these ratios, but I submit that 
the reductions following both the 1932 and 1935 Manitoba amendments were not co-incidental. Guest passenger legislation was not the result of any abstract notions of fairness or any intense fear of dishonest drivers. It was the result of a decision-a quite understandable decision-that the limits of the insured risk must be narrowed in response to the economic pressures of depression times.

It is time that this emergency measure of the 1930's should be repealed, and the risk again expanded to provide greater protection for those who are injured by automobiles. Unquestionably, this would cost money; premiums would have to rise. The premium increase would not be excessive, however. It was estimated in 1962 that the complete abolition of the guest passenger exemption in Ontario would result in an annual premium increase of $\$ 7.00$ to $\$ 9.00$ per policy..$^{25}$ At that time, there was an absolute prohibition on actions by guest passengers in Ontario. In other provinces (some of which have lower insurance rates to begin with) where drivers are already liable for gross negligence or wilful and wanton misconduct, the increase would undoubtedly be much less. To provide compensation to so important a category of traffic victims, I submit that such an increase would be entirely justifiable.

Looking at all of the reasons that have been advanced in support of guest passenger discrimination, it is difficult to disagree with the writer who said:

... it seems clear that the various reasons, taken collectively or one at a time, offer but scant excuses for interfering in such a drastic manner with the ordinary civil rights of a gratuitous passenger.26

No group of persons is more familiar with the operation of guest passenger legislation than the legal profession. It would be unfair to say that the legal profession unanimously opposes the legislation. There is no subject about which lawyers hold a unanimous view, and many lawyers undoubtedly support the guest passenger statutes. Yet there are a few observations that can confidently be made about the legal profession's attitude which illustrate the unsatisfactory nature of the legislation.

No lawyer even casually familiar with this area of law would deny that it bristles with cases in which, because of a desire to provide compensation for an injured guest passenger, the court has placed a strained and unnatural interpretation on the words of the legislation. A guest passenger who fell through faulty floor-boards of a car when it was in motion was allowed to recover, because the driver's negligence related to the passive condition of the car rather than to the act of driving. ${ }^{2 i}$ When two hitchhikers were picked up by the driver of a government truck, and one was injured because of the negligence of the other hitchhiker, who had been allowed to drive, the injured passenger succesfully sued both the other hitchhiker and the regular driver. The guest passenger section was held to be inapplicable because the injured passenger was the guest of neither the "operator" (the other hitchhiker) nor the "owner" (the government). ${ }^{28}$ A guest passenger who helped his driver

25 Law Society of Upper Canada, The Present System of Compensating Automobile Accident Victims in Ontario, 13.

26 R. L. Pierce, Liability to Gratuitous Aircraft Passengers, [1965] Can. Bar Assoc. Papers 43, 52

2i Houweling v. Wesseler (1963), 40 D.L.R.(2d) 956 (Ont. C.A.).

28 Carson v. Dinnin (1962), 33 D.L.R. (2d) 128 (Man. C.A.). 
assist the driver of a stalled car by standing on the bumpers of the two cars while one was being pushed by the other, and was injured due to the negligence of his driver, was allowed to recover, despite the legislation, for two reasons- (a) by standing on both cars he was a passenger of neither, and (b) he was not being carried on the bumpers for the purpose of personal transport, but to assist in moving the front car. ${ }^{29} \mathrm{~A}$ guest passenger injured while being driven by a co-employee in the employer's car in the course of his employment was held entitled to recover compensation from the employer, because the statute was interpreted as applying only to liability as owner or operator, not to liability as employer..$^{\text {so }}$ Such illustrations could be multiplied almost infinitely, but the cases mentioned should be sufficient to demonstrate that many courts are so dissatisfied with the legislation that they are prepared to narrow it by interpretation, so that many situations to which it was intended to apply are not covered. Unfortunately, however, this is not a uniform attitude on the part of the courts; some judges are much more creative in their interpretations than others. The result is that a litigant is frequently unsure whether the legislation will prevent his recovery of compensation.

Virtually every lawyer who has written on the subject has opposed the legislation. ${ }^{31}$ The late Dean $\mathrm{C}$. Wright of the University of Toronto law faculty expressed his opposition somewhat more emphatically than most when he described the former Ontario section as one of "the most vicious pieces of legislation which an active insurance lobby was able to foist on an unsuspecting public,"32 but most legal writers seem to feel as strongly as he did about the need for repeal.

The Canadian Bar Association considered the matter during its 1965 convention. A paper favouring repeal of the discrimination was delivered to the Insurance Law section ${ }^{33}$ and another, on a related topic, to the Air Law section. ${ }^{34}$ After a debate in the Insurance Law section and in the open convention, the following resolution was passed:

Resolved that the Canadian Bar Association recommend that the present restrictions existing in certain provincial legislation on claims by guest passengers in motor vehicles be removed. ${ }^{35}$

It is time to translate this resolution into legislative action. Discrimination against guest passengers must be ended.

29 Lachner v. Neath (1966), 58 D.L.R.(2d) 662 (Sask. C.A.).

30 Co-operator's Insurance v. Kearney (1965), 48. D.L.R. (2d) 1 (Sup. Ct. Can.).

31 See, for example:

Chief Justice J. C. McRuer. The Motor Car and the Law (1966), Osgoode Hall L.J. $54,66$.

Dean $C$ C. A. Wright, case comment (1945), 23 Can.B.Rev. 344.

MacArthur, Gross Negligence and the Guest Passenger (1960), 38 Can. B. Rev. 47.

Horsley, Manual of Motor Vehicles Law 228 (1963)

New Zealand, Report of the Committee on Absolute Liability 13 (1963) J. A. Griffin, The Restriction on Guest Passenger Claims, [1965] Can. Bar Assn. Papers,

A. M. Linden, book review, (1964) 42 Can. B. Rev. 337.

R. L. Pierce, supra, n. 26.

B. Kushner, supra, n. 15.

32 Id., at 347.

33 Griffin, supra, n. 31

34 Plerce, supra, n. 26

35 (1965), 48 Proceedings of the Can. Bar. Ass. at 105-108 and 219-220. The voting appears to have been quite close. 